\title{
Defining elements and challenges of a Pentecostal hermeneutics of experience
}

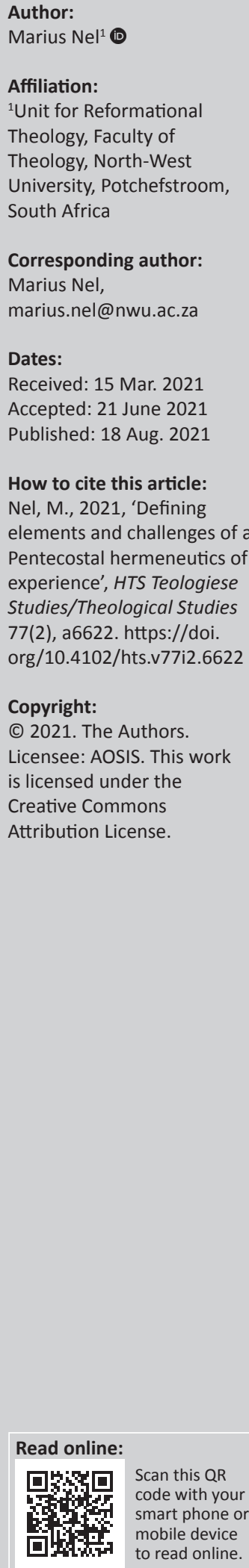

The article intends to describe the distinctive elements and challenges of a Pentecostal hermeneutics of experience, consisting of charismatic encounters with the Spirit that condition and determine both classical Pentecostals' spirituality and hermeneutics. The research is based on a comparative literature study and auto-ethnographical observations. The findings include that Pentecostals hold to a 'high view' of the Bible (like most conservative Protestants), but their ethos includes and emphasises the experiential. Their experiences form their pre-understanding (Vorverständnis). At the same time, they expect the Spirit to generate insights that apply the text to their context. Thus, although they accept traditional hermeneutical principles, they also interpret the text from their charismatic experiences and the affections accompanying it. The distinctive of the hermeneutics of experience is that Pentecostals rely on the Spirit's revelation in the reading process because of the expectation to experience direct divine revelations and the miraculous as in biblical times. The result is that it subjects the formulation of doctrine to the experiential because it bases its epistemology on an intimate relationship with God through Christ, and not on knowledge acquired by rational means. The challenge is that it may lead to individualist and subjectivist (and at times, far-fetched) (mis)interpretation of texts.

Contribution: The article concludes that the collectivist control of the individual interpretation of texts alone can safeguard the faith community, as in the practice of the interpretation of tongues and prophecy.

Keywords: experiential; affects; Holy Spirit; revelation; continuationism; supranatural; subjectivity.

\section{Introduction}

Researchers recognise the necessity to be critical towards one's presuppositions in any hermeneutical enterprise. It is relevant to theology, where diverse paradigms lead to different interpretations of key Scripture passages and the defining of doctrines that differ between traditions (and even within one tradition). The article limits itself to the one aspect of the hermeneutical process that is especially relevant in classical pentecostal practice: how personal experiences and related affections influence and inform its Bible's reading practices. ${ }^{1}$ The article discusses the defining elements of a hermeneutics of experience before it discusses the challenge it faces that the affectionate can lead to a subjectivist interpretation.

For Pentecostals, experiences and affections play a prominent, significant and integral role in their spirituality, reflected in the hermeneutical processes they employ in understanding the Bible. They see the Bible not just as an ancient literary collection, but a testimony of God's participation in humanity's history (Smit 1998:343) and the product of the Spirit's involvement in the generation, preservation, transmission and interpretation of faith.

Believers' experiences and affections are intricately linked together. The influence of experiences and affections among Pentecostals differs in some respects from its influence in other traditions and forms an integral part of the presuppositions underlying a Pentecostal's hermeneutic that need to be set out and described. Pentecostal Bible-reading practices' dynamic features demonstrate and point to a greater reality of God's actions in the world, expecting God to act as

1.Within classical Pentecostalism, three hermeneutical developments exist, distinguishing early Pentecostal Bible reading practices from the acceptance of conservative literalist practices in association with Evangelicals since the 1940s, and a new hermeneutics developed in pentecostal scholarship since the 1980s that link to some aspects of early practices (Nel 2019:72-90). The article's discussion is defined by the new pentecostal hermeneutics and represents an emic (insider) rather than an etic (outsider) approach towards Pentecostalism. 
an active, causative agent in the church of the day as God did in biblical times. In the next section, the distinctive elements of the hermeneutics of experience are analysed.

\section{Pentecostal hermeneutics and experience}

Classical Pentecostals share with many conservative Protestants a 'high' view of Scripture; the Bible is God's authoritative, reliable and inspired ('God-breathed') word. The Bible has a divine origin as the sign and instrument of God's loving address to intelligent creatures (Webster 2003:42) and serves as the word of God in some sense (sacra scriptura est verbum Dei) - God's self-revelation and loving address to human beings. Pentecostals view the ultimate purpose of the Bible as Christian formation (Philemon 2019:205) and view the 56 books of the Protestant Bible as canonical (Nel 2020:1), identifying with a segment of Protestant experience in general (Maier 1994:411-412).

'Pentecostal' hermeneutics also shares with these traditions the emphasis that a consensus of scholars' agreement is essential for any hermeneutical process. Traditional principles universally used for reading include the importance of interpreting a passage in the light of its immediate context, reading it for its function within and as a part of the rest of the book, and reading it in the light of the cultural context that its language, assumptions and allusions take for granted (Keener 2016b:117). It includes discounting the specific genre or literary type, respecting the historical and social contexts in which the text originated, and giving attention to the original listeners or readers' social context. Ample room should also be left for authors' distinctive voices that may reflect different theological and ideological traditions within the Bible and identify ideological elements that protect the powerful in texts. Finally, one should also affirm the overarching narrative, scopus and fundamental theological unity of the canon as the revelation of God's salvation to humankind.

However, it is contended that there are some aspects in Pentecostal hermeneutics that are distinctive, although not necessarily unique to the Pentecostal movement. ${ }^{2}$ These presuppositions are concerned with what is distinctive about being a Pentecostal and representative of the pentecostal ethos, values and interests because these factors dictate the interests they carry into their reading and influence their understanding, as McKinlay (2001:159-171) explains. These elements consist of believers' personal experience of Spirit baptism and being led daily by the Spirit, interpreted from the vantage of the day of Pentecost (Ac 2; Keener 2016b:4), providing a different framework from conservative, dispensational Evangelicalism (Lewis 2000:95). ${ }^{3}$ For that reason, Pentecostals emphasise that hermeneutic, consisting of charismatic experiential presuppositions; the pneumatic; genre; exegesis; and experiential verification.

3.'Experience' refers to 'a complex, conscious, affective, psychological phenomenon' that involves both cognitive awareness of external events and internal physiological affective and consciouos reactions to such events, in Parker's (1996:15) terms. 'Charismatic experience' refers to encounters with God through the Spirit as defined in pentecostal practice. one needs to interpret the Bible with the enlightenment of the Spirit who had inspired it.

\section{Experiential in hermeneutics}

The condition in Pentecostal hermeneutics is charismatic experiences that, in the first place, form a pre-understanding (Vorverständnis) that determines what they take into the text whilst interpreting the text and influences the text's interpretation and application personally and culturally (Lewis 2000:113-114). In other words, the experience of the Spirit's baptism (Ac 1:5) or filling (Ac 2:4) that empowered the church on the day of Pentecost to proclaim the gospel 'to the ends of the earth' dynamically shapes Pentecostals' reading of Scripture. Thus, the direction in which they read Scriptures is from their experiences to the Bible and back.

In the second place, Pentecostals deliberately expect to hear from God directly whilst reading the Bible. They are open to the 'voice of the Spirit', expecting the Spirit to interpret Scripture and apply it to their context through insights formed in their minds (Pinnock 1993):

The Spirit is active in the life of the whole church to interpret the biblical message in the languages of today. He actualises the word of God by helping us to restate the message in contemporary terminology and apply it to fresh situations. The result is that salvation history continues to take effect in us. (p. 4)

The insights they believe they receive from the Spirit (and that are not necessarily or always directly connected to the text) form an integral and essential element of their hermeneutics, spirituality and the eventual theological formation. They share the anticipation of an encounter with God in their reading of Scripture and expect that the encounter will transform their life. 'The impetus for reading biblical texts in the Pentecostal community is to obtain transformative encounters with God' (Grey 2011:154) that consists of the ability to change behaviour, regulate decisions and set parameters for a reader's life influenced by the biblical text (Lewis 2000:116).

The Pentecostal hermeneutical spiral implies that orthodoxy, orthopathy and orthopraxy intermingle in the interpretation process (Lewis 2000:117). They view their encounter with charismatic experience as a necessary and even critical voice in biblical hermeneutics' conversation (Grey 2011:5). That is the reason why pentecostal hermeneutics is qualified here as a 'hermeneutics of experience'.

Such experiences provide a form to their spirituality and determine how they interpret the Bible. In the process, they reinterpret biblical events to fit into their existential reality and explain the meaning of what happens in their lives from such parallels. For this reason, Ellington (1996:38) argues that: 'Pentecostal theology and hermeneutics are different 
because they arise not primarily out of rational reflection, but rather out of lived experience' ${ }^{4}$

Although rational deliberations do not necessarily have emotional content, most experiences are affections-based; that is why rich emotional content characterises charismatic spirituality. It may serve as a reason why some mainline churches became interested in integrating aspects of charismatic worship practices and spirituality. It also explains the popularity and growth of Pentecostalism in the global South, including Africa (Kalu 2008:5).

One cannot argue with the observation that Pentecostal readings of the Bible lead to mixed results. For instance, they accommodate differing views of Trinitarianism, several ethical issues, women's role in ministry, prosperity teachings, separation from the world and ascetical injunctions and prescriptions. In addition, one can discern a mainstream tradition contra diverse local cultural applications (Archer 2017:193). The reason is that Pentecostals do not have any magisterium to decide what is to be considered 'Pentecostal' (Chapman 1990:269). There are no publications by a pioneer or important leader/figure(s) or an overarching organisation, synod or council that they view universally as authoritative.

\section{Relying on the Spirit}

The next defining element of Pentecostal hermeneutics consists of the Spirit's inspiration and revelation as a condition for understanding the Bible correctly. Pentecostals believe that the Spirit can act in ways that do not necessarily comply with the rules of more rational approaches and bring people into a more profound knowledge of God by using the Bible (May 2005:7). What does it imply that the Bible reader should rely upon the Holy Spirit in interpreting the text?

Humanly devised interpretative methods will always be marred by several limitations, illustrating the need for divine guidance and requiring a continuous reflection on the Spirit's role in interpretive practices (Philemon 2019:31). It implies that interpretive exercise may never be predominantly a human academic enterprise. Arrington (1994:105) suggests several helpful ways in which interpreters may express their dependence on the Spirit. By submitting the mind to God, readers deliberately bring their critical and analytical abilities under the Holy Spirit's guidance with a genuine openness to the witness of the Spirit as they examine the text. They realise that the Spirit addresses them in ways that transcend human reason. The Spirit flows in ways that no one can control or dictate, implying that one should approach the Bible, not as an object to interpret but as a living word that interprets readers (Moore 2013:11-13). For that reason, Bible-reading practices should ideally occur within the context of prayer and worship that results in charismatic experiences and relationaltransformation knowledge of Christ (Nebeker 2003:49).

4.'Theology' is used here to refer to the second-order affair that proceeds in abstraction from first-hand experience (Yong 2002:2); one should also remember abstraction from first-hand experience (Yong 2002:2); one should also remember
that Pentecostals interpret and verbalise their personal experiences from biblical precedents, explaining the ground of their theology (see discussion later).
Jones and Jones (1992:112) describe Pentecostal epistemology (the way Pentecostals acquire knowledge) by the Hebrew term yajda - 'to know', which they interpret as 'knowledge which comes through experience'. Knowledge is more of the actualisation of a relationship than a mere conceptualisation of an object (Moore 2013:12). The Pentecostal community does not amass knowledge in reading the Bible for knowledge's sake but from their desire to 'know' God (Grey 2011:159).

The challenge is that relying on the Spirit can lead to subjectivist interpretation practices, and therefore Pentecostals must keep the two dimensions, experientialpneumatic (or spiritual) and exegetical elements of the interpreting process, in balance. ${ }^{5}$ They should realise that an overemphasis of the experiential and pneumatic at the cost of the mind's contribution contributes to a subjectivising interpretative process; the last part of the article comes back to the challenge. They should remember that the Bible should always stand as the objective standard and submit all interpretation to it; this is non-negotiable. To speak with any authority, a pneumatic reading condition is that it can support its case biblically. Pentecostals believe that God still speaks today, and when God speaks, God has more to say than just what is written in the Bible. However, what God says will never contradict what Scripture teaches because it is the same Spirit who inspired the Bible's authors who reveal God to contemporary believers (Archer 2013:148).

The last remark is that the interpretation is not exhausted by commentary alone; the ceaseless movement of biblical interpretation begins and ends in the challenge of a response, in the words of Ricoeur (1975:31). Hermeneutics reminds us that biblical faith is inseparable from the movement of interpretation, which elevates it into a language (Gräbe 1997:23). Pentecostals interpret faith in the same terms as the book of Acts; it consists of life-transforming encounters with God that empower believers to tell about the divine power and love that changed their lives and eventually established a faith community (Schnackenburg 1974:81-82).

\section{Pentecostalism's continuationism}

The next element of a hermeneutics of experience is the expectation of a continuous divine revelation of some sort. Pentecostals expect to hear from the Spirit when they worship, pray and read the Bible, and they define their spirituality within these existential parameters. They interpret their charismatic experiences in continuity with the experiences ascribed to the early church of the first century and use it as a starting point or pre-understanding for engaging the text (Kärkkäinen 2002:38). The expectation of restoring the New Testament church's essential practices comes from a primitivist urge to receiving an ongoing revelation. It distinguishes them from the (soft and hard) cessationism of most Protestant traditional 'mainline' churches.

5.It is acknowledged that although an objectivist reading of the biblical text (like always finding the original intention of the author) is impossible, what is needed is an interpretation that relies upon a consensus among believers. 
They believe that they live in some sense within the larger narrative world of the Bible, sharing the world view of Jesus and the apostles and establishing their metanarrative in terms of the Bible's narratives, characterised by the super/ supranatural, eschatological and apocalyptic world view that foresees a catastrophic end of the existing order. The metanarrative serves as a means of shaping identity, which in its turn contributes to experience and understanding.

Pentecostals' purpose in reading the Bible is not merely to collect information about biblical figures and historical events or to understand the text that originated in an ancient culture. As a faith community, they believe that they live in the biblical experience, demonstrated by their (perceived) experience that the same Spirit who guided God's people and inspired the Bible still leads them in the same way. At the same time, they use language generated by reading the Bible and derived from the Bible when they testify about their encounters with God. In this way, they succeed to bring together the ancient and contemporary horizons of understanding in a unique manner; their narrative world coincides with that of biblical figures. They base their noncessationist or continuationist approach to the Bible on their identity founded on their experiences of Spirit baptism that formed them into a prophetic-eschatological people of God as interpreted in terms of Joel 2:28-32 and Acts 2:21 (Keener 2016a:231; Martin 2013:1). 'Being pentecostal' implies that one is committed to a Spirit-centred, miracle-affirming, praise-oriented version of Christian faith that fits the New Testament description, in Jacobsen's (2003:12) words. When they read the Bible, they expect to share the same experiences and relationships with God that they find in the Bible. For that reason, they read the text and interpret it as a source that addresses the questions they pose to the text (Bultmann 1984:79). They leave ample space that the Spirit, the still 'voice of God', will reveal insights, ${ }^{6}$ expecting the Spirit to apply a specific passage to a new situation (Van der Geest 1998:40). It implies that the text's meaning can move beyond the scope of the authors' intent. It accepts that the humans who participated in the Bible's writing did not always fully understand what they wrote, implying that there may be a sensus plenior that the Spirit may wish to explicate for contemporary readers. New contexts may also generate new meanings in line with the biblical metanarrative (Lewis 2000:113). They read biblical narratives as 'testimonies', implying, according to Brueggemann (1997:118), that they do not ask, 'What happened? but What is said? Furthermore, what does it say to me?' One implication is a simplistic acceptance of the narrative's claims as authentic and accurate, including historical references, resonating with pentecostal tendencies towards literalism. ${ }^{7}$

6.Not all Pentecostal scholars agree. Anderson (1992:12), for example, argues that the Spirit does not act upon the mind that enables the human being to intellectually Spirit does not act upon the mind that enables the human being to intellectually grasp the revelation of the Bible, but on the will of the individual. He reasons that anyone who can read or hear can understand what the Bible says; one does not need the guidance of the Spirit to do so. 'The Spirit's role is not to shed light upon the meaning of the text itself, but to move the will of the in
receptivity to the meaning of scriptures' (Noel 2007:260).

7.Narrative criticism explains that the acceptance of the claims of the story is important, disconnecting the meaning of the text from questions of history, because
Continuationism implies that biblical narratives relate how people heard from God, spoke 'God's words' and experienced miracles of deliverance and healing. Contemporary Pentecostals expect that God would repeat similar interventions in their lives and circumstances. The expectation includes supranatural wonders and miracles; the result is that the 'supernatural' element within the community forms an integral element of Pentecostalism's essence (Archer 2013:131) because God as an active agent includes the miraculous intervention of God operating outside a rationalist worldview (Grey 2011:169). Pentecostals' world view is more holistic than the average Westerners', incorporating 'natural' and 'supernatural' alongside each other without any qualms. It is based on what Poloma (1989:8) calls an anomaly that maintains a tension between the 'rational cognitive and affective experiential'. They operate their worship gatherings on the assumption that God can and will do what God wants, and they reject a formal liturgical structuring of worship services to provide the Spirit that opportunity (Davies 2013:253). It is crucial for them that their worship services keep the spontaneity where the Spirit may at any time intervene as the Spirit wills. They create the space that any one of the attendees may participate by testifying, singing, praying or bringing a charismatic word. In this way, they confirm the priesthood and prophethood of all believers, including all people, despite gender, age or level of (theological and other) education.

The first part discussed the defining elements of a hermeneutics of experience that emphasise the role the experiential plays in interpretation, the importance of relying on the Spirit whilst reading and the primitivist expectation of a repetition of biblical revelation. The Pentecostal hermeneutics also determines how Pentecostals theologise; again, they start from their experiences and move to the theoretical.

\section{Pentecostals, doctrine and authority}

Pentecostals' hermeneutics of experience holds significant implications for their theological endeavours. Although the Bible serves as the standard to define faith and practice (Nel 2017:2), they base their doctrine on their experiences with the God who utilises the Bible to reveal Godself through God's Spirit (Ellington 1996:34). According to Grey (2011):

The orientation toward and through experience can be described as an epistemology in which religious truths are not objects of abstract belief (i.e., belief as cognition), but are living facts experimentally known as personal, first-hand knowledge. (p. 14)

They define doctrine experientially in terms of the Bible or based on what they perceive as similar experiences found in the Bible, although they underplay doctrine to the benefit of ongoing encounters with God and continuous revelation. Their epistemology is open-ended. Doctrine is emphasised only within the praxis and not as creedal representation; not imply that the claims are necessarily true and based on actual historical events. 
creeds do not function in any way in their spirituality. However, they set (and should always do so) as a condition for their experience of ongoing revelation that canonical texts serve as 'measuring sticks' for such encounters. However, the challenge and danger remain the exploitation and abuse of the interpretation of texts in the service of ideological or personal agendas (Keener 2016b:107-108).

Pentecostals read the Bible to find something they would experience as relevant to their felt needs (Anderson 2013:222). Then the Bible becomes the word of God, as Luther and Barth emphasised, because of the Spirit's ministry, something that does not happen automatically or mechanically when believers read the Bible but require Bible reading in the context of prayer, worship and dedication to God. Pentecostal hermeneutics sees the Bible as a witness to revelation rather than revelation itself; the actual, real inspiration of the Spirit occurs when the texts are read faithfully (as Barth 1958:512 also states). Only when reading the Bible results in a revelation applicable to the current situation does the Bible become the word of God. The Spirit's authority comes before and determines the Bible's authority (Land 1993:100, 106; Welker 1996:52-79). For Pentecostals, cognitive constructs alone do not determine the Bible's authority; instead, their immediate experiences of God in and through the text do it (Lewis 2000:110).

Pentecostal hermeneutics is based upon God's continued presence globally, working the same way today as God did in biblical times (McKay 1994:29). The expectation is that a modern-day believer can experience existentially what the earliest apostles experienced by cooperating with the same Spirit (Martin 2013:2) and accompanied by the same charismatic phenomenology that characterised the earliest church (Ervin 1981:22). In that sense, the Bible's authority is self-evident because believers find that the text relates to their experiences that coincide with the text (Lewis 2000:111). God's voice is, for that reason, not limited to the words of the Bible, but recognised in present-day anointed sermons, teachings, exhortations, testimonial narratives and other charismatic words, including the charismata (Albrecht 1999:229).

\section{Faith community as a guarantee against affectional subjectivism}

In discussing the most significant hermeneutics of experience, several challenges were identified, such as the affectionate leading to a subjectivist interpretation and the ideological exploitation and abuse of interpretation. Experience and its accompanying affections are necessarily individualist and subjectivist, even in communal experiences within groups, necessitating measures to prevent subjectivist and ideological misinterpretation. It is suggested that a three-tiered process can counteract the dangers of subjectivist readings that requires the Pentecostal faith community's participation. ${ }^{8}$

8.See also Bird's (1982:83-85) three principles that she offers for ensuring responsible reading practice, as studying the Bible as a life-long process, within the context of the faith community and the compatibility of experiential knowledge.
The three-tiered questions that should be asked are: what does the text mean to me (an individual), to them (the wider church through the ages) and us (the local faith community)? These voices' interaction provides Pentecostals with controls against the loud domination of a single voice, acknowledging the difficulty of analytically isolating God's propositional content from God's personal communion and offers 'checkpoints' against 'me', 'them' and 'us'.

As a community of believers, the church is the context for biblical interpretation, a pneumatological fellowship whose origin and sustenance is contingent upon the Holy Spirit (Philemon 2019:208), in the same way as the faith community also serves as a corrective for charismatic practices. Charismatic words aspire to represent a (new) word of revelation from God to upbuild, encourage and console fellow believers (1 Cor 14:3); the rest of the believers are responsible to judge or weigh it (1 Cor 14:29).

As stated, Pentecostal hermeneutics appreciates the text's transformative power in the interaction between the reader's experience and the text and provides meaning. However, stopping here and not integrating the meaning into the broader community's understanding imply that the text is not read beyond its significance for the individual. When readers expound on 'new truths' or read the Old Testament through exclusively 'christological lenses' and find many narratives of prototypes and prophecies of Christ, it demonstrates the limitation and liability of isolated readers (Grey 2011:155). They need a critical interaction and dialogue with the Pentecostal and broader Christian community to ensure that one eliminates the dangers inherent in self-deception. Pentecostals should learn to question the text's significance for others, including the marginalised (the 'them') such as people of other races, the poor, women, displaced people and people with other sexual orientations (Smit 1998:346). They should deliberately relate their understanding to the faith community's understanding and ensure that interpretation aligns with the ecumenical community's broader historical and current exegetical perspectives. The exercise of charismata implied in the faith community's existence as a 'community of the Holy Spirit' may also provide affirmation of the correctness of their interpretation; gathering together as believers is a fundamental Pentecostal expression in which they believe the Spirit speaks and operates through the gifts (Philemon 2019:63).

In this regard, Thomas (1994:43) suggests a holistic Pentecostal hermeneutic that leaves room for the revelation of the Spirit and believers' experiences. He refers to Acts 15, explaining that the Spirit cooperates with the faith community to interpret the requirement whether gentile or non-Jewish Christians should observe the Mosaic law as in Judaism. The believing community interprets their context in terms of the biblical text, in contrast to exegetical processes that

9.The history of Pentecostalism provides many examples of prominent spiritual leaders who influenced parts of the church and its interpretation of texts, illustrating the need for communal checks on Bible interpretation. 
move in the opposite direction by beginning with the text and moving to the context. The last element is the Spirit's revelation that enlightens the faith community in the interpretive process, leading to the remark that it has seemed good to the Holy Spirit and to us to impose on you ...' (Ac 15:28). Pentecostals do not claim, as Evangelicals do, that the Spirit only illuminates their minds; instead, they expect the Spirit to guide them to understand God's will in the challenges their context poses to them.

The interpretation process then consists of the three components of Spirit, faith community and interpretation (Sparks 2008:192) that dialogue with each other when the community searches the Bible for the Spirit's revelation to meet their context's challenges. Firstly, it requires a dynamic conversation between the believer, the Spirit, the Bible and the faith community (Ellington 1996:28); then, 'what the Bible says' and 'what God says' become identical (Ellington 1996:38).

In conclusion, the primary technique for avoiding the potential of rampant subjectivism in interpretation requires the necessity of a continuing dialogue in Bible interpretation, reading in conversation with 'them' and 'us'.

\section{Synthesis}

The article intended to delineate the defining elements of a Pentecostal hermeneutics of experience and discuss the challenges it imposes on Bible-reading practices. Pentecostals argue that in the same way that the Spirit guided biblical authors in writing down what became the Bible, human interpreters need the experience of the guidance and illumination of the Spirit to understand the text. Moreover, experience hermeneutics' epistemology is not primarily based on knowledge acquired by rational means but through an intimate relationship with God through Christ. Hence, this knowledge has life-transforming power, transcending a merely cognitive recognition of a set of principles.

It found that Pentecostal hermeneutics should always start the reading practice from the context of readers' charismatic experiences, whilst also leaving room for the Spirit to interpret what biblical authors intended to say concerning the current challenges of the faith community. Thus, although it does not deny the text's original meaning, it leaves room for the Spirit to address new settings and challenges through insights that develop in readers' minds.

It also found that the Pentecostal community played a significant role to counteract the challenges of individuals' subjectivist interpretations. The faith community is the primary interpreter of the Bible and of charismata, and the necessary interpretive accountability is only possible within the Christian community equipped with the gift of the discernment of spirits (1 Cor 12:10). Therefore, especially Pentecostals, in their expectation to hear from God, should resist the tendency of extensive individualism in biblical interpretation, ensuring that their experience-certified hermeneutics is also community-driven. The believing community's priority is to interpret Scriptures through the Spirit with vigilance and attentiveness.

\section{Acknowledgements}

The author thanks the National Research Foundation (NRF) of South Africa for providing funding for this study. The views expressed do not necessarily reflect the view of the NRF.

\section{Competing interests}

The author declares that he has no financial or personal relationships that may have inappropriately influenced him in writing this article.

\section{Author's contributions}

M.N. is the sole author of this article.

\section{Ethical considerations}

This article followed all ethical standards for research without direct contact with human or animal subjects.

\section{Funding information}

The NRF provided funding for this study.

\section{Data availability}

Data sharing is not applicable to this article as no new data were created or analysed in this study.

\section{Disclaimer}

The views and opinions expressed in this article are those of the author and do not necessarily reflect the official policy or position of any affiliated agency of the author and the publisher.

\section{References}

Albrecht, D.E., 1999, Rites in the Spirit: A ritual approach to Pentecostal/ charismatic spirituality, Journal of Pentecostal Theology Supplement 17, Cheffield Academic, Sheffield.
Sharismatic spirituality, Journel

Anderson, A.H., 2013, An introduction to Pentecostalism, 2nd edn., Cambridge University Press, Cambridge.

Anderson, G.L., 1992, 'Pentecostal hermeneutics', in Drinking from our own wells: Defining a Pentecostal-charismatic spirituality, Conference papers, vol. 2, twentysecond annual meeting of the society for Pentecostal studies, Assemblies of God Theological Seminary, November 12-14, Springfield, MO, viewed n.d., from https://biblicalstudies.org.uk/th_spirit_ch1.html.

Archer, K.J., 2013, 'Pentecostal hermeneutics: Retrospect and prospect', in L.R. Martin (ed.), Pentecostal hermeneutics: A reader, pp. 131-148, Brill, Leiden.

Archer, K.J., 2017, 'Spirited conversation about hermeneutics: A Pentecostal hermeneut's response to Craig Keener's Spirit Hermeneutics', Pneuma 39(1/2), 179-197. https://doi.org/10.1163/15700747-03901007

Arrington, F.L., 1994, 'The use of the bible by Pentecostals', Pneuma 16(10), 101-107. https://doi.org/10.1163/157007494X00085

Barth, K., 1958, Church dogmatics, I/2:19.2, eds., G.W. Bromiley \& T.F. Torrance, T\&T Clark, Edinburgh.

Bird, P.A., 1982, The Bible as the church's book, Westminster, Philadelphia, PA.

Brueggemann, W., 1997, Theology of the Old Testament: Testimony, dispute, advocacy, Fortress, Minneapolis, MI. 
Bultmann, R., 1984, 'The problem of hermeneutics', in S.M. Ogden (ed.), New Testament mythology and other basic writings, pp. 69-93, Fortress, Philadelphia, PA.

Chapman, M.E., 1990, 'The Spirit and the magisterium: Authority in the community of freedom', The Ecumenical Review 42(3-4), 268-278. https://doi. org $/ 10.1111 / j .1758-6623.1990 . t b 02656 x$

Davies, A., 2013, 'What does it mean to read the bible as a Pentecostal?', in L.R. Martin (ed.), Pentecostal hermeneutics: A reader, pp. 249-62, Brill, Leiden.

Ellington, S.A., 1996, 'Pentecostals and the authority of scriptures', Journal of Pentecostal Theology 4(9), 16-38. https://doi.org/10.1177/096673699600400902

Ervin, H.M., 1981, 'Hermeneutics: A Pentecostal option', Pneuma 2(2), 11-25. https:// doi.org/10.1163/157007481X00098

Gräbe, P.J., 1997, 'Hermeneutical reflections on the interpretation of the New Testament with special reference to the Holy Spirit and faith', in P.J. Gräbe \& W.J. Hattingh (eds.), The reality of the Holy Spirit in the church: In honour of F. P. Möller pp. 14-26, J.L. Van Schaik, Pretoria.

Grey, J., 2011, Three's a crowd: Pentecostalism, hermeneutics, and the Old Testament, Pickwick, Eugene, OR.

Jacobsen, D., 2003, Thinking in the Spirit: Theologies of the early Pentecostal movement, Indiana University Press, Bloomington, IN.

Jones, C.B. \& Jones, J.J., 1992, 'Yielding to the Spirit: A Pentecostal approach to group bible study', Journal of Pentecostal Theology 1, 109-134. https://doi. org/10.1177/096673699200100108

Kalu, O., 2008, African Pentecostalism: An introduction, Oxford University Press, Oxford.

Kärkkäinen, V.-M., 2002, Pneumatology: The Holy Spirit in ecumenical, international, and contextual perspective, Baker Academic, Grand Rapids, MI.

Keener, C.S., 2016a, Mind of the Spirit: Paul's approach to transformed thinking, Baker Academic, Grand Rapids, MI.

Keener, C.S., 2016b, Spirit hermeneutics: Reading scripture in light of Pentecost, Eerdmans, Grand Rapids, MI.

Land, S.J., 1993, Pentecostal spirituality: A passion for the kingdom, CPT, Cleveland, OH.

Lewis, P.W., 2000, 'Towards a Pentecostal epistemology: The role of experience in Pentecostal hermeneutics', The Spirit and Church 2(1), 95-125.

Maier, G., 1994, Biblical hermeneutics, transl. R.W. Yarbrough, Crossway, Wheaton, IL.

Martin, L.R., 2013, 'Introduction to pentecostal biblical hermeneutics', in L.R. Martin (ed.), Pentecostal hermeneutics: A reader, pp. 1-9, Brill, Leiden.

May, R.J., 2005, The role of the Holy Spirit in biblical hermeneutics, viewed 05 March 2021, from www.biblicalstudies.org.uk.

McKay, J., 1994, 'When the veil is taken away: The impact of prophetic experience on biblical interpretation', Journal of Pentecostal Theology 5, 17-40. https://doi. org/10.1177/096673699400200503

McKinlay, J.E., 2001, 'What do I do with contexts? A brief reflection on reading biblical texts with Israel and Aotearoa New Zealand in mind', Pacifica 14(2), 159-171. https://doi.org/10.1177/1030570X0101400203
Moore, R.D., 2013, 'A Pentecostal approach to scripture', in L.R. Martin (ed.), Pentecostal hermeneutics: A reader, pp. 9-13, Brill, Leiden.

Nebeker, G.L., 2003, 'The Holy Spirit, hermeneutics, and transformation: From present to future glory', Evangelical Review of Theology 27(1), 47-54.

Nel, M., 2017, 'The Pentecostal movement's view of the continuity of tongues in Acts and 1 Corinthians', In die Skriflig 51(1), a2198. https://doi.org/10.4102/ids.v51i1.2198

Nel, M., 2019, An African Pentecostal Hermeneutic: A distinctive contribution to Hermeneutics, Wipf \& Stock, Eugene, OR.

Nel, M., 2020, 'Pentecostal canon of the bible?', Journal of Pentecostal Theology 29(1), 1-17. https://doi.org/10.1163/17455251-02901001

Noel, B.T., 2007, 'Pentecostal and postmodern hermeneutics: Comparisons and contemporary impact', DTh dissertation, University of Pretoria.

Parker, S., 1996, Led by the Spirit, Journal of Pentecostal Theology Supplement 7 , Sheffield Academic Press, Sheffield.

Philemon, L., 2019, Pneumatic hermeneutics: The role of the Holy Spirit in the theological interpretation of Scripture, CPT, Cleveland, TN.

Pinnock, C.H., 1993, 'The work of the Holy Spirit in hermeneutics', Journal of Pentecostal Theology 1(2), 3-23. https://doi.org/10.1177/096673699300100201

Poloma, M.M., 1989, The assemblies of God at the crossroads: Charisma and institutional dilemmas, University of Tennesse Press, Knoxville, TN.

Ricoeur, P., 1975, 'Philosophical hermeneutics and theological hermeneutics', Studies in Religion/Sciences Religieuses 5(1), 14-33. https://doi. org/10.1177/000842987600500103

Schnackenburg, R., 1974, Belief in the New Testament, transl. J. Moiser, Paulist, New York, NY.

Smit, D.J., 1998, 'Biblical hermeneutics: The 20th century', in S. Maimela \& A. Kőnig (eds.), Initiation into theology: The rich variety of theology and hermeneutics, pp. 337-347, Van Schaik, Pretoria.

Sparks, K.L., 2008, God's word in human words: An evangelical appropriation of critical biblical scholarship, Baker Academic, Grand Rapids, MI

Stronstad, R., 1992, 'Pentecostal experience and hermeneutics', Paraclete 26(1), 14-30.

Thomas, J.C., 1994, 'Women, Pentecostals and the bible: An experiment in pentecosta hermeneutics', Journal of Pentecostal Studies 5, 41-56. https://doi. org/10.1177/096673699400200504

Van der Geest, S., 1998, 'Participant observation in demographic research: Fieldwork experiences in a Ghanaian community', in A. M. Basu \& P. Aaby (eds.), The methods and uses of anthropological demography, pp. 39-56, Clarendon, Oxford.

Webster, J., 2003, Holy scripture: A dogmatic sketch, Cambridge University Press, Cambridge.

Welker, M., 1996, 'Word and Spirit, Spirit and word: A Protestant response', Concilium 3, 52-79.

Yong, A., 2002, Spirit-word-community: Theological hermeneutics in trinitarian perspective, Ashgate new critical thinking in religion, theology, and biblical studies, Ashgate, Aldershot. 